Фармацевтична технологія, біофармація, гомеопатія Pharmaceutical technology, biopharmacy, homeopathy

Рекомендована д. фрармац. наук, профр. Т. Г. Калинюком УДК 615.847.8:541.8

\title{
ВСТАНОВЛЕННЯ УМОВ СТАБІЛІЗАЦІї МАГНІТНИХ НАНОЧАСТИНОК У СКЛАДІ СИСТЕМ МАГНІТОКЕРОВАНОГО ТАРГЕТІНГУ ЛІКАРСЬКИХ РЕЧОВИН
}

\author{
(CI. О. Ведерникова \\ Національний фрармацевтичний університет, Харків
}

Резюме: досліджено агрегативну та седиментаційну стійкість магнетитових дисперсних систем на водній основі. Розроблено стійку дисперсну систему ПЕО/магнетит без застосування ПАР. Модифікація поверхні магнітних частинок із використанням розчину $\mathrm{HCl}$ та поліелектролітів (пектину, натрій олеату) збільшує стійкість систем на 60 \%. Методом ІЧ-спектроскопії встановлено хімічну взаємодію молекул стабілізатора з приповерхневими катіонами фреруму магнетиту.

Ключові слова: наночастинки магнетиту, стабілізація, магнітокеровані системи доставки ліків.

Вступ. Останнімчасомпоширені роботиізрозробки та аналізу магнітокерованих систем доставки ліків до «органу-мішені» (магнітний таргетінг) під дією зовнішнього магнітного поля [1-4]. Умови стабілізації магнітних наночастинок таких систем можуть визначатися структурно-реологічними властивостями дисперсійного середовища. У разі використання полярного дисперсійного безструктурного середовища (такого, як вода) стійкість систем може бути досягнута використанням електростатичних та стеричних фракторів стабілізації. У пластично-пружнов'язкому середовищі стабілізація частинок магнетику можлива без використання поверхнево-активної речовини (ПАР), через силу в'язкого опору дисперсійного середовища.

Для подібних систем слід оцінювати характер взаємодії адсорбент - адсорбат між частинками магнітної фрази та молекулами стабілізатора (або середовища), який впливає на стан поверхні та приповерхневих шарів магнітних наночастинок, а отже, на їх магнітні властивості та на величину міжчастинкової магнітної взаємодії [5-8].

На даний час нанотехнології з використанням частинок магнетиків у складі фрармацевтичних засобів тільки набувають свого розвитку. Встановлення умов одержання стабільних дисперсних систем, які за своїм складом та фрункціональними характеристиками можуть бути використані як магнітокеровані системи доставки ліків $€$ актуальним завданням, що відповідає тенденціям сучасної світової науки.

Мета роботи: вивчити агрегаційну та седиментаційну стійкість синтезованих частинок магнетиту у різних за структурно-реологічними властивостями дисперсійних середовищах. Для розроблених систем провести оцінку зв'язку «адсорбент - адсорбат» між частинками магнітної фрази та молекулами стабілізатора.

Методи дослідження. Досліджували зразки суспензій наночастинок магнетиту на водній основі (як стабілізатор використовували натрій олеат, 0,5 \% водний розчин хлоридної кислоти , 3 \% водний розчин пектину) та на основі сплаву поліетиленоксидів (ПЕО1500:ПЕО400 8:2). Синтез частинок магнетиту проводили методом хімічного співосадження - середній діаметр частинок $<d>=20$ нм, рентгенівська

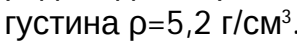

Величину -потенціалу визначали експериментально методом рухомої межі. Седиментаційну стійкість дисперсій вивчали за зміною оптичної густини суспензій - фоотоколориметр ЛМФ-72М. Для встановлення характеру адсорбційної взаємодії молекул натрій олеату з магнетитом були проведені ІЧ-спектроскопічні дослідження у діапазоні 400$4000 \mathrm{~cm}^{-1}$ (у таблетках KBr).

Результати й обговорення. Одержані значення електрокінетичного потенціалу дослідних систем та результати седиментаційних досліджень наведено в таблиці 1. Було встановлено досить високі значення електрокінетичних $\xi$-потенціалів усіх дослідних систем. Додавання стабілізаторів призводило до збільшення потенціалу в середньому на $45 \%$ та константи седиментаційної стійкості на 60 \%. Ефективність використання електролітів пояснюється утворенням подвійного електричного шару на поверхні часинок магнетиту.

Найкращі показники мають суспензії з використанням розчину пектину (аніонний поліелектроліт). На поверхні міцелярного ядра (частинки магнетиту) адсорбуються аніони D - галактуронової кислоти (основна складова речовина пектину). При цьому молекули стабілізатора розміщені на межі розподілу фраз таким чином, що своєю полярною (зарядженою) частиною вони зорієнтовані до полярної фрази, а неполярною - до неполярної, утворюючи мономолекулярний сольватний шар. Це призводить до збільшення стійкості дисперсійної системи, сприяє просторовому структуруванню колоїдних частинок (гранул).

ISSN 2312-0967. Фармацевтичний часопис. 2015. № 2 
Фармацевтична технологія, біофармація, гомеопатія

Pharmaceutical technology, biopharmacy, homeopathy

Таблиця 1. Електрокінетичні потенціали дисперсних систем, середній розмір та ступінь агрегації частинок магнітної фрази

\begin{tabular}{|c|c|c|c|c|c|}
\hline \multirow[t]{2}{*}{ № зразку } & \multirow[t]{2}{*}{ Склад дисперсної системи } & \multirow{2}{*}{ 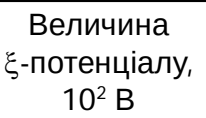 } & \multicolumn{3}{|c|}{$\begin{array}{c}\text { Середній розмір частинок, нм / ступінь } \\
\text { агрегації, \% }\end{array}$} \\
\hline & & & 1 доба & 7 днів & 60 днів \\
\hline 1 & магнетит/вода & 4,28 & $120 / 40$ & $120 / 40$ & $120 / 40$ \\
\hline 2 & магнетит/5 \% розчин $\mathrm{HCl} /$ вода & 6,28 & $60 / 10$ & $60 / 10$ & $60 / 10$ \\
\hline 3 & магнетит/натрій олеат/вода & 6,95 & $80 / 20$ & $80 / 20$ & $80 / 20$ \\
\hline 4 & $\begin{array}{c}\text { магнетит/3 \% розчин пектину/ } \\
\text { вода }\end{array}$ & 7,08 & $80 / 20$ & $80 / 20$ & $80 / 20$ \\
\hline
\end{tabular}

Окремого розгляду, на наш погляд, заслуговує розробка дисперсної системи наночастинок магнетику у пластично-пружнов'язкому середовищі (без застосування ПАР), яка може бути використана у складі м'яких лікарських фрорм як основа з магнітокерованими властивостями. Введення магнітного компоненту до складу мазі розширює можливості місцевого лікування, призводить до появи нових прийомів застосування мазевих композицій з використанням дії зовнішнього магнітного поля.

Розроблено алгоритм одержання дисперсної системи частинок магнетиту у ПЕО з застосуванням ефекту П. О. Ребіндера та правила Б. В. Дерягіна. Одержана мазеподібна композиція вже при $29^{\circ} \mathrm{C}$ перетворюється на густу рідину і може бути скерована та утримана зовнішнім магнітним полем, при цьому не розшаровується і поводить себе як єдина крапля. Встановлено, що розроблена дисперсна система ПЕО/магнетит відповідає умовам седиментаційної стійкості: мала швидкість осідання магнітної фрази $\left(2,15 \cdot 10^{-9} \mathrm{~cm} / \mathrm{c}\right)$ та високі значення міри кінетичної седиментаційної стійкості $\left(4,5 \cdot 10^{5}\right)$. Величини зумовлені високими значеннями структурно-реологічних показників дисперсійного середовища та високодисперсним розміром магнітної фрази. Це дозволяє одержати стійку систему без застосування стабілізаторів, використовуючи структурно-механічний фрактор стійкості.

Характер адсорбційної взаємодії молекул стабілізатора з магнетитом визначали аналізом ІЧ-спектрів співвідношенням характеристичних смуг експериментальних зразків порівняно зі смугами вихідних речовин (рис. 1).

На одержаних спектрах дослідних зразків (рис. 1 a, б), спостерігається широка смуга середньої інтенсивності у діапазоні 3200 - 3600 см-1 $^{-1}$ пов'язана з характеристичними коливаннями ОН-груп. Смуги поглинання, що реєструються у спектрі зразку магнітокерованої системи (рис. 1, б), зумовлені наявністю в молекулах води та солі олеїнової кислоти гідроксильних груп (область 2950 - $2850 \mathrm{~cm}^{-1}$ ), валентними коливаннями карбонільного зв'язку C=O $\left(1712\right.$ см$\left.^{-1}\right)$, зв'язку C=C (інтенсивна смуга при $1457 \mathrm{~cm}^{-1}$ та 1377 см$\left.^{-1}\right)$. Піки при 2953 та $2854 \mathrm{~cm}^{-1}$ відповідають коливанням груп $-\mathrm{CH}_{2}$ та $-\mathrm{CH}_{3}$. Сигнали при $1457 \mathrm{~cm}^{-1}$ та $1377 \mathrm{~cm}^{-1}$ - десрормаційні коливання -CH груп молекул натрій олеату.
У спектрі зразка наночастинок магнетиту (рис. 1, a) відмічається наявність смуги зв'язку Fe-O 3 максимумом при значені $570 \mathrm{~cm}^{-1}$, що добре узгоджується 3 відомими даними [5-10]. Гіпсохромний ефрект відповідної смуги поглинання у зразку магнітної системи (рис. 1, б) та її роздвоєння (587 $\mathrm{cm}^{-1}$ та $\left.634 \mathrm{~cm}^{-1}\right)$ можна пояснити впливом молекул стабілізатора, зокрема їх взаємодією з приповерхневими катіонами фрерума магнітних наночастинок. Сигнали при $890 \mathrm{~cm}^{-1}$ - 790 см $^{-1}$, відповідають деформаційним коливанням гідроксогруп, що асоційовані з катіонами ферума магнетиту. Вони присутні в обох спектрах, але у зразку магнітної системи (рис. 1, б) вони помітно збільшуються за інтенсивністю. Одержані результати демонструють утворення зв'язку між молекулами натрій олеату та частинками магнетиту. Можна припустити, що йде утворення водневих зв'язків та взаємодія 3 утворенням $\mathrm{Fe}_{3} \mathrm{O}_{3} \mathrm{OCO}$ - груп.

Хімічна взаємодія з молекулами стабілізатора атомів поверхні магнітних частинок призводить до змен-

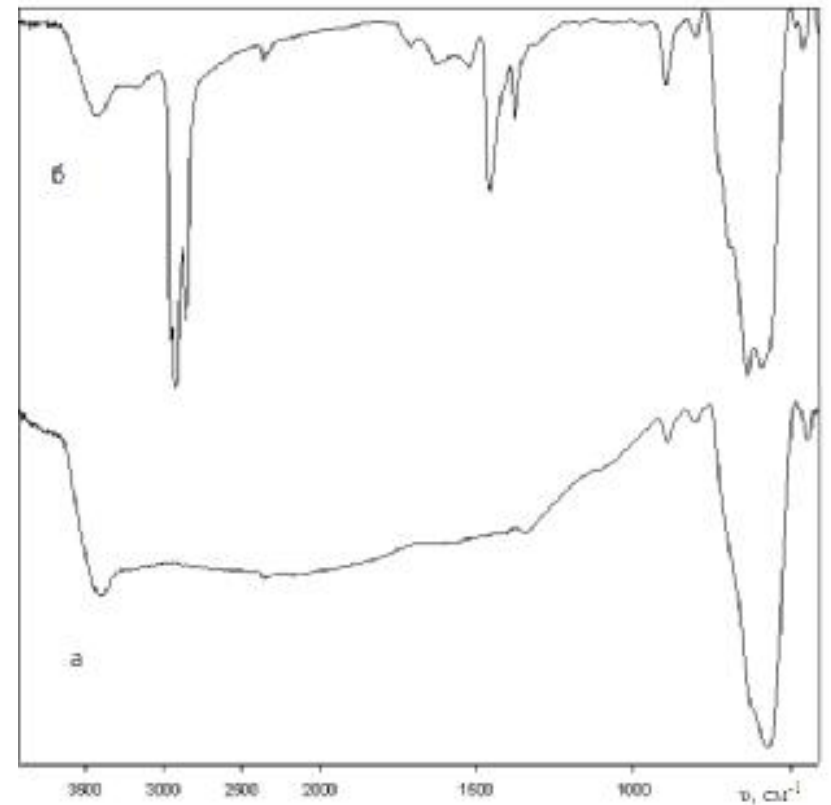

Рис. 1. ІЧ-спектри поглинання синтетичних наночастинок магнетиту (а), магнітокерованої системи магнетит/натрій олеат/вода (б).

ISSN 2312-0967. Pharmaceutical review. 2015. № 2 
Фармацевтична технологія, біофармація, гомеопатія Pharmaceutical technology, biopharmacy, homeopathy

шення «магнітного розміру» частинки. До того ж, надмірна локальна концентрація молекул стабілізатора на поверхні частинки утворює щільний парамагнітний шар. Таким чином, з одного боку, необхідність присутності ПАР зумовлена перешкоджанням агрегації частинок у середовищі 3 невисокими показниками структурно-механічного опору, з іншого, використання стабілізатора (олеїнової кислоти та її солей) призводить до зниження магнітних властивостей такої системи, що треба враховувати.

Висновки. При дослідженні електроповерхневих властивостей магнетитових дисперсних систем на водній основі встановлено, що використання розчину хлоридної кислоти, натрій олеату та пектину як стабілізаторів призводить до збільшення стійкості дисперсної системи (та ל-потенціалу) і сприяє просторовому структуруванню колоїдних частинок. Додавання стабілізатора сприяє збільшенню кінетичної седиментаційної стійкості магнетитової фази у воді в середньому на $60 \%$.

Методом ІЧ-спектроскопії визначений характер зв'язку в системі адсорбент-адсорбат для системи частинок магнетиту в складі суспензії на водній основі. При співвідношенні характеристичних смуг експериментального зразка магнітної системи з натрій олеатом до спектральної картини магнетиту засріксовано хімічну взаємодію молекул стабілізатора з приповерхневими катіонами ферума магнетиту.

\section{Література}

1. Vizirianakis I. Nanomedicine and personalized medicine toward the application of pharmacotyping in clinical practice to improve drug-delivery outcomes / I. Vizirianakis // Nanomedicine. - 2011. - №7. - P. 11-17.

2. Zahn M. Magnetic fluid and nanoparticle applications to nanotechnology / M. Zahn // Journal of nanoparticle research. - 2001. - №3. - P. 73-78.

3. Indira T. K. Magnetic nanoparticles / T. K. Indira, P. K. Lakshmi // International J. of Pharm. Sci. and Nanotech. - 2010. - Vol. 3, № 3. - P. 1035-1042.

4. Saiyed Z. Application of magnetic techniques in the fields of drug discovery and biomedicine / Z. Saiyed, S. Telang, C. amchand // Biomagnetic Res. and Tech. - 2003. - Vol.1, №2. - P. 1021-1030.

5. Preparation and properties of poly(acrylic acid) oligomer stabilized superparamagnetic ferrofluid / C. Lin, C. Lee, W. Chiu [et al.] // Journal of Colloid and Interface Science.

- 2005. - Vol. 291. - P. 411-420.

6. Chang $\mathrm{H}$. A study on dynamic stability of the $\mathrm{Fe}_{3} \mathrm{O}_{4}$ magnetorheological fluid / H. Chang, K. Tsai, T. Tsung // Materials Science Forum. - 2007. - Vol. 561. - P. 21752178.

7. Pegnology: a review of PEG-ylated system /D. Bhadra, S. Bhad-ra, P. Jan, N. Jain // Pharmazie. - 2002. - № 57. - P. 5-27.

8. Synthesis and characterization of biocompatible $\mathrm{Fe}_{3} \mathrm{O}_{4}$ nanoparticles / J. Sun, S. Zhou, P. Hou [et al.] // J. Biomed. Mater. Res. A. - 2006. - № 10. - P. 333-341.

9. Magnetic field synthesis of $\mathrm{Fe}_{3} \mathrm{O}_{4}$ nanoparticles used as a precursor of ferrofluids / R. Y. Hong, T. T. Pan, Y. P. Han [et al.] // JMMM. - 2007. - № 310. - P. 37-47.

10. Wang L.S. Synthesis, surface modification and characterisation of nanoparticles / L. S. Wang, R. Y. Hong // Advances in Nanocomposites. - 2008. - № 34. - P. 289-322.

\section{ОПРЕДЕЛЕНИЕ УСЛОВИЙ СТАБИЛИЗАЦИИ МАГНИТНЫХ НАНОЧАСТИЦ В СОСТАВЕ СИСТЕМ МАГНИТОУПРАВЛЯЕМОГО ТАРГЕТИНГА ЛЕКАРСТВЕННЫХ ВЕЩЕСТВ}

\section{И. А. Ведерникова \\ Национальный фрармацевтический университет, Харьков}

Резюме: изучены седиментационная и агрегативная устойчивость магнетитовых дисперсных систем на водной основе. Разработана устойчивая дисперсная система ПЭО/магнетит без использования ПАВ. Модификация поверхности магнитных частиц с использованием раствора $\mathrm{HCl}$ и полиэлектролитов (пектина, олеата натрия) увеличивает устойчивость систем на 60 \%. Методом ИК-спектроскопии установлено химическое взаимодействие молекул стабилизатора с приповерхностными катионами железа магнетита.

Ключевые слова: наночастицы магнетита, стабилизация, магнитоуправляемые системы доставки лекарств. 


\section{STUDYING THE CONDITIONS OF STABILIZATION OF MAGNETIC NANOPARTICLES IN A MAGNETIC} TARGETING DRUG SYSTEMS

\section{O. Vedernykova}

National University of Pharmacy, Kharkiv

Summary: aggregation and sedimentation stability of magnetite dispersed water-based systems were studied. Stable dispersion system PEO/magnetite without the use of surfactants was developed. Surface modification of the magnetic particles using a solution of $\mathrm{HCl}$ and polyelectrolytes (pectin, sodium oleate) increases the stability of the systems by $60 \%$. Using IR-spectroscopy the chemical interaction of SAR molecules with the surface layer of magnetite iron cations was determined.

Key words: magnetite nanoparticles, stabilization, magnetically drug delivery systems. 